\title{
Amyotrophic lateral sclerosis (ALS) disease clusters in the United States and international sites: Association with glacial lakes and clay minerals
}

Kavitha Reddy, M.D.

Harvard Vanguard Medical Associates, Boston, Massachusetts

Email: kreddy@bu.edu

Keywords: amyotrophic lateral sclerosis, ALS, glacial, lake, clay, mineral, United States, Canada, Finland, Vermont, New Hampshire, Maine, Ohio, Wisconsin, Indiana, Minnesota, North Dakota, Montana, Idaho, Washington, Oregon, Colorado, Iowa, Utah

\begin{abstract}
Amyotrophic lateral sclerosis (ALS) disease clusters are found in several countries worldwide. In the United States, ALS clusters are found in many states, largely within the northern United States. The cause of the increased rates of ALS in these areas remains indefinite. It is reported here that many ALS clusters are associated with sites of current or prior glacial lakes, or regions containing an abundance of silts and clay minerals. The potential significance of these findings in ALS is discussed.
\end{abstract}




\section{Introduction}

Amyotrophic lateral sclerosis (ALS) is a neurodegenerative disease of protein misfolding. This devastating disease leads to progressive muscular paralysis and early death in affected individuals. Sporadic ALS, the most common type of the disease, is believed to develop after exposure to one or more as yet unidentified toxin(s). There may be a common environmental factor underlying certain disease clusters. ${ }^{1,2}$

ALS disease clusters have been found concentrated in particular regions in several countries. ${ }^{1}$ ALS disease clusters in the United States have been identified in several locations within the northern United States, as well as in a few nearby states such as Colorado and Utah. ${ }^{2,3}$ Aluminosilicate and phyllosilicate minerals present as a result of glacial sediments, weathered volcanic rocks, clays, and other sources may be an underlying environmental factor in ALS. ${ }^{4}$ Here the association of ALS disease clusters in the United States and in several international countries with areas of historic or current glacial lakes, having a high proportion of glacial silt and clay mineral deposits, is described and explored.

\section{Lake Champlain, Vermont}

An increased incidence of amyotrophic lateral sclerosis has been documented in several locations along the eastern shore of Lake Champlain. ${ }^{3}$ The affected towns include Burlington, Shelburne, Swanton, St. Albans, Essex Junction, Colchester, and Winooski, Vermont. ${ }^{3}$ Lake Champlain is the residual body of water that is now present at the site of the larger historic Champlain sea and the historic glacial Lake Vermont (Figure 1). The Lake Champlain Valley is described as a "lowland developed on glacial and marine sediments". ${ }^{5}$ There are steep clay banks along sections of the lake and significant amounts of clay on and in the lakebed floor. ${ }^{5}$ Shales, which contain a high proportion of clay minerals, are also prominent in the area. The Lake Champlain Valley, which includes the lake itself and adjacent now-dry land, contains ground with a high proportion of fine sediments, silts and clays, including aluminosilicates, kaolin, and zeolites amongst others. ${ }^{5,6}$ Lacustrine or glaciolacrustine deposits consisting of these fine sediments are a prominent feature of the region. Glaciolacrustine deposits may contain several mineral types, although montmorillonite, illite, and chlorite are common components. Montmorillonite has been identified in Shelburne, Vermont and illite and chlorite, 2:1 phyllosilicates, have been found in sediments in the lake. Since the abundant clays in the region are poorly characterized, the possibility remains of the further presence of these and other similar clay minerals over further areas within the Lake Champlain Valley region. Geologic formations rich in clay minerals are prominent along the eastern shore of the lake ${ }^{7}$, which may explain the localization of ALS disease clusters along this section. Manganese nodules are also present in several locations of the lake..$^{5}$ Manganese, in high amounts, may cause neurologic disease including parkinsonism, and the possibility that it could also cause symptoms of ALS 
has been considered by some authors. ${ }^{8}$ The effects of chronic low-level exposure are also of potential concern to scientists, but have not been well-determined. ${ }^{8}$ Clay minerals can also bind and store a variety of toxins. Bio-accumulation of clay minerals, manganese, or both in fish or seafood that is then frequently consumed is another potential source of human exposure to these substances in ALS-affected regions. A large portion of the affected area sources drinking water from Lake Champlain. Drinking water is obtained from wells or other sources in much of Vermont as well. In general, very small clay minerals can potentially remain in drinking water despite standard efforts at water monitoring and treatment, and these levels can increase or decrease at any given time depending on a variety of environmental conditions.

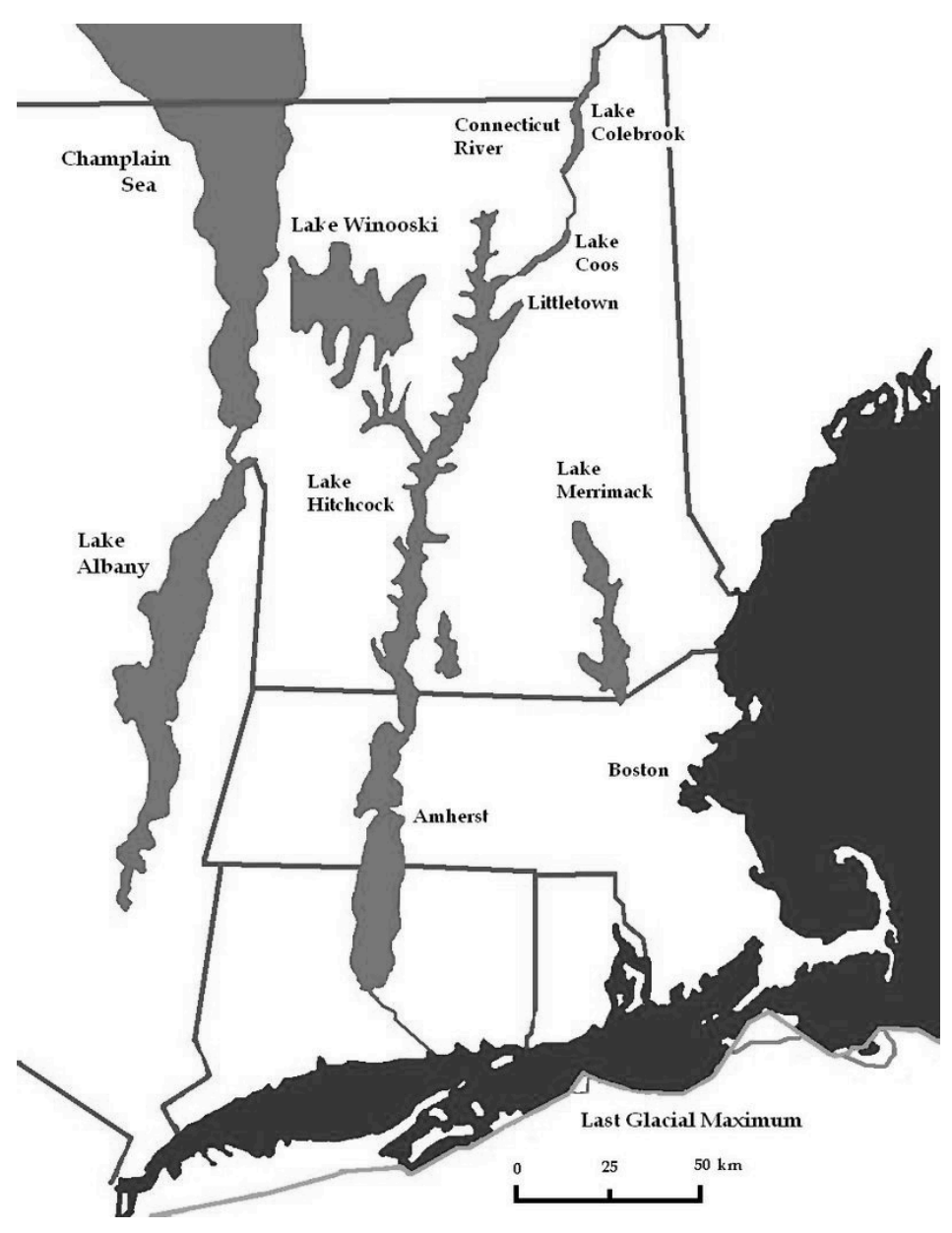

Figure 1.

Proglacial and prehistoric lakes of New England during the end of the Wisconsin Glacial Epoch of the Pleistocene Era. ${ }^{9}$ Source: Chris Light. Wikipedia, Lake Hitchcock. 


\section{North-Central Vermont}

An area of increased ALS incidence is also found at the nearby north-central portion of Vermont, including the Montpelier and Stowe regions. ${ }^{3}$ The water supply to Montpelier comes from Berlin Pond, described by one source as a shallow, silty pond. This north-central area of the state is in the region of historic glacial lakes Lake Stowe and Lake Winooski (Figure 1). This suggests an increased rate of ALS may be linked to an area potentially high in silts and clay minerals, remnants of the glacial lake that was once in the region, and provides a potential explanation for increased rates of ALS in inland areas without current large water body exposures.

\section{Upper Valley, New Hampshire Southeastern New Hampshire}

ALS disease clusters in the Upper Valley region of New Hampshire have also been identified, including the area bordering Lake Mascoma in Enfield, New Hampshire. ${ }^{3}$ This area contains abundant glacial sediments of several major varieties, including rocks, till, silt, sand, and clay. ${ }^{10}$ The large ancient glacial Lake Hitchcock centered on the Upper Valley region (Figure 1). ${ }^{9}$ There also appears to be a region with a density of ALS cases a short distance west of the southeastern corner of New Hampshire. ${ }^{3}$ This area appears to coincide with the region of historic glacial Lake Merrimack (Figure 1). Geologic studies show a notable presence of silts and clays along this site. ${ }^{11}$

\section{Bangor, Maine \\ Southern Maine}

Amyotrophic lateral sclerosis cases in Maine appear to be concentrated in the southern portion of the state, along the coastline and in the city of Bangor. ${ }^{3}$ These areas coincide with the area of the state where the Presumpscot Formation is found and where glacial silts and clays are prominent. ${ }^{12}$ Fluvial and other finesediment deposits are also found in northeastern Maine, ${ }^{12}$ where an increased incidence of ALS has also been found. ${ }^{2}$

\section{Lake Erie, Conneaut, Ohio}

The city of Conneaut, Ohio borders Lake Erie, and has had several cases of ALS. Lake Erie, as one of the Great Lakes, and Conneaut have a strong glacial history as well. ${ }^{13}$ Glaciolacustrine deposits are found in this area, located at the southern portion of Lake Erie, bordering Ashtabula County of northern Ohio. Sediments, alluvial deposits, clays, and shale are present in the region and likely contain aluminosilicates. Manganese can also be found in the water of Lake Erie and can increase under certain conditions, including hypoxic conditions in the lake and may represent another potential concern in this region. 


\section{Indiana}

In Indiana, a group of several counties affected with higher-than-expected ALS incidence has been reported in the region south of Indianapolis. ${ }^{2}$ This area is the site of glaciolacustrine sediments from previous glacial lakes such as Lake Quincy and from glacial lake meltwater sluiceways that were historically present in the region. ${ }^{14}$

\section{Wisconsin}

Waupaca county, Wisconsin, may have one of the highest ALS incidence rates in the United States. ${ }^{2}$ Several other nearby counties in Wisconsin also have high rates of ALS. ${ }^{2}$ Wisconsin is situated on the western border of Lake Michigan, and heavy glacial effects in the region contributed to the formation of the Great Lakes. In addition, the sites of historic glacial lakes Oshkosh, glacial Lake Wisconsin, and lands likely to have incurred glacial meltwater floods are found in or near the area15,16 of many of the counties affected with increased rates of ALS.

\section{Minnesota, North Dakota, and South Dakota}

Areas of high ALS incidence are found over much of Minnesota, and are scattered in North and South Dakota. ${ }^{2}$ Minnesota was the site of an expansive historic glacial lake, Lake Agassiz, that was among the largest glacial lakes in North America, and both Minnesota and North Dakota also contained several associated smaller glacial lakes. ${ }^{17}$ South Dakota contains the Black Hills region, which is known for its abundant mineral resources including modern bentonite clay mineral deposits.

\section{Montana, Idaho, Washington state, and Oregon}

Historic Lake Missoula flood paths extended from northwestern Montana westward through the northwestern tip of Idaho into northeastern Washington. They then continued down through southeastern Washington, into the northeastern border of Oregon (where an ALS hotspot is found), and into the northwestern Oregon cascades area (Figure 2). ${ }^{18}$ These areas all show an increased incidence of ALS. ${ }^{2}$ In addition an area of increased incidence of ALS is found along the western portion of Washington state in a group of counties where previous glacial lake flooding likely occurred from glacial Lake Carbon and events of the historic Puget Lobe glaciation. 


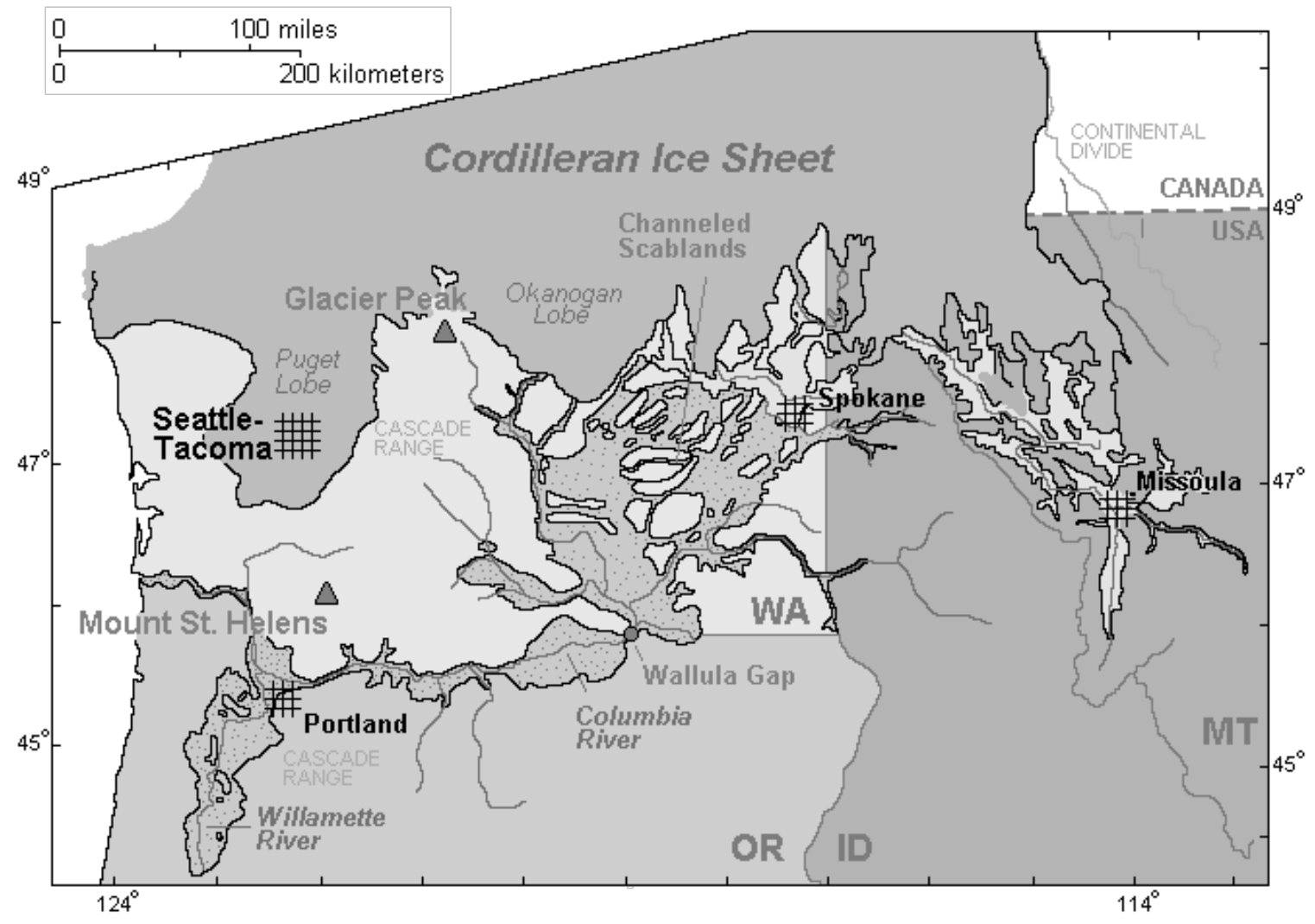

Figure 2.

Map of the Missoula Floods. Source: United States Geological Survey, United States Department of the Interior. ${ }^{18}$

\section{Utah, Colorado, and Iowa}

The mid-portion of the Western border of Colorado shows an increased incidence of ALS. ${ }^{2}$ This region corresponds with the Colorado Grand Valley that is rich in residual glacial effects including fine sediments. ${ }^{19}$ Another affected area of the state, at the mid-portion of the northern border, has a history of glacial activity as well. In Utah, regions showing a moderately increased rate of ALS appear to correspond with the region of historic glacial Lake Bonneville. ${ }^{20}$ In Iowa, there is a group of counties at the central to slightly southern region of the state with an increased incidence of ALS. ${ }^{2}$ These counties correspond well to the historic area of the glacial Des Moine lobe and glacial remnants are prominent in the area today. ${ }^{21}$

\section{Canada, Greenland, and Iceland Sweden, Norway, and Finland}

Spatial clusters of increased motor neuron disease incidence are also present in several countries around the world. ${ }^{1}$ Canada, Greenland, Iceland, Sweden, Norway and Finland are among those countries that show the highest rates of ALS. ${ }^{1}$ 
Each of these far-northern countries has prominent past and current glacial characteristics. In Finland, two prominent ALS disease clusters have been identified, one in south-central Finland and one in southeastern Finland. ${ }^{22}$ These disease clusters correspond with the regions of two large lakes formed by glacial meltwaters, lakes Paijanne and Saimaa. The southern to southeastern portion of Finland is also characterized by the glacial Salpausselka ridge system, and contains many glacial sediments in the area including silts and clays. ${ }^{23}$

\section{Discussion}

As ALS, Parkinson's disease and other diseases of protein misfolding have remained some of the most mysterious and difficult diseases to understand, many potential risk factors and hypotheses are regularly explored by those interested in prevention and treatment of these conditions. Varied mineral exposures are in some sense ubiquitous, and therefore one must remain cautious when considering whether the association is one of coincidence or one of significance. Studies and experiments to confirm potential ALS risk factors are of critical importance. Mineral exposures are seen in many areas, including those away from lakeshores. ${ }^{4}$ Well water can contain natural ground minerals or be contaminated by minerals from pesticide products. Bentonites are also often used to seal wells. Aluminosilicates are further used by a wide variety of industries and individuals. ${ }^{4} \mathrm{An}$ increased rate of ALS has also been described in sports players, most notably baseball, soccer, and football players. ${ }^{4}$ A possible explanation based on the mineral hypothesis includes the common use of clay in the creation and maintenance of various athletic fields, especially baseball, soccer, and football fields. For example, application of topdressing or soil conditioning using calcined clay, a form of montmorillonite, is a common sports practice. Clay is also regularly used on professional league baseballs and on baseball fields. There may be a benefit of mitigation against reasonable and practically addressable risk factors until the definitive cause of ALS can be identified. Utilizing water from sources that are less likely to contain clay minerals could be considered, at least for those regions affected with higher ALS incidences. Zeolites share many similar properties with clay minerals, and might similarly be avoided until further study is completed. Water treatment and testing to remove clay minerals, including removal of sub-micron or nanometer-sized particles, is also a potential consideration. Local fish and shellfish might be at risk of bioaccumulation of minerals or toxins, and the possibility of human effects from frequent consumption may also be considered. Continued investigation of a variety of possible exposures common to regions affected with increased rates of ALS is encouraged until we understand the cause of sporadic amyotrophic lateral sclerosis. 


\section{References}

1. GBD 2016 Motor Neuron Disease Collaborators. Global, regional, and national burden of motor neuron diseases 1990-2016: a systematic analysis for the Global Burden of Disease Study 2016. Lancet Neurol 17:1083-97 (2018).

2. Schwartz GG, Rundquist BC, Simon IJ, Swartz SE. Geographic distributions of motor neuron disease mortality and well water use in U.S. counties. Amyotrophic Lateral Sclerosis and Frontotemporal Degeneration, 18: 3-4, 279-283 (2017).

3. Caller TA, Chipman JW, Field NC, Stommel EW. Spatial Analysis of Amyotrophic Lateral Sclerosis in Northern New England, USA, 1997-2009. Muscle Nerve 48: 235241 (2013).

4. Reddy K. Bentonite exposure in Western Pacific amyotrophic lateral sclerosis/ Parkinsonism Dementia Complex and neurodegenerative diseases. Preprints 31 May (2020).

5. Detenbeck JC (Editor). The geology of the Lake Champlain basin and vicinity. Vermont Geological Society. 1: 1-40 (1980).

6. Middlebury College Clay Symposium. Clay Soils of the Champlain Valley. Accessible: http://www.middlebury.edu/media/view/422894/original/ 5_clay_soils_champl_valley_alves.pdf (2012).

7. Doll, CG (Editor). Surficial geologic map of Vermont. Accessible: https://dec. vermont.gov/sites/dec/files/geo/StatewidePubs/SurfMapopt.pdf (1970).

8. Bowman AB, Gunnar FK, Hernandez EH, Aschner M. Role of manganese in neurodegenerative diseases. J Trace Elem Med Biol 25(4): 191-203 (2011).

9. Chris Light. Proglacial and prehistoric lakes of New England during the end of the Wisconsin Glacial Epoch of the Pleistocene Era. (Original in color) Wikipedia. "Lake Hitchcock." 24 Sep (2019).

10. Denny CS. Surficial Geology of the Canaan Area New Hampshire. Geological Survey Bulletin 1061-C (1958).

11. Goldthwait, JW. The surficial geology of New Hampshire. Accessible: https://ngmdb.usgs.gov/Prodesc/proddesc_42595.htm (1950).

12. Maine Geological Survey. Simplified surficial geologic map of Maine. Accessible: http://www.colby.edu/biology/BI237/handouts/surficial11x17.pdf (2003) 
13. White GW, Totten SM. Glacial geology of Ashtabula County, Ohio. Ohio Division of Geological Survey, no. 112 (1979).

14. Thornbury, WD. Glacial sluiceways and lacustrine plains of southern Indiana. State of Indiana, Division of Geology (1950).

15. Clayton JA, Knox JC. Catastrophic flooding from Glacial Lake Wisconsin. Geomorphology 93: 384-397 (2008).

16. Wisconsin Geological and Natural History Survey. Green Bay and Fox River lowland. Accessible: https://wgnhs.wisc.edu/wisconsin-geology/major-landscapefeatures/green-bay-fox-river-lowland/

17. Bluemle, JP. Glacial Lake Agassiz. North Dakota Geological Survey. Accessible: https://www.dmr.nd.gov/ndgs/ndnotes/agassiz/

18. Wikipedia contributors. Missoula Floods. (Original in color) Wikipedia 8 Dec (2020).

19. Sinnock S. Glacial moraines, terraces and pediments of Grand Valley, western Colorado. In Western slope (Western Colorado), New Mexico Geological Society 32nd Annual Fall Field Conference guidebook p.113-120 (1981).

20. Link PK, Kaufman DS, Thackray GD. Field Guide to Pleistocene Lakes Thatcher and Bonneville and the Bonneville Flood, Southeastern Idaho. In Hughes SS, Thackray GD (editors), Guidebook to the Geology of Eastern Idaho: Idaho Museum of Natural History, p.251-266 (1999).

21. Prior, JC. Landforms of Iowa. University of Iowa Press (1991).

22. Sabel CE, Boyle PJ, Loytonen M, Gatrell AC, Jokelainen M, Flowerdew R, Maasilta P. Spatial clustering of amyotrophic lateral sclerosis in Finland at place of birth and place of death. Am J Epidemiol 157: 898-905 (2003).

23. Nenonen J, Portaankorva A. The geology of the Lakeland Finland area. Geological Survey of Finland (2009). 